\title{
Effectiveness of Social Support Group Interventions for Psychosocial Outcomes: A Meta-analytic Review
}

\author{
Arissa A. Brunelli, ${ }^{1}$ Gregory C. Murphy ${ }^{2}$ and James A. Athanasou ${ }^{3}$ \\ ${ }^{1}$ School of Applied Psychology and Behavioural Basis of Health, Griffith University, Gold Coast, \\ Australia \\ ${ }^{2}$ School of Psychology and Public Health, La Trobe University, College of Science, Health and \\ Engineering, Melbourne, Australia \\ ${ }^{3}$ Faculty of Health Sciences, Discipline of Rehabilitation Counselling, University of Sydney, \\ Sydney, Australia
}

\begin{abstract}
$\mathrm{T}$ his study investigated the effectiveness of support groups for people living with chronic ill-health conditions. Searches of the published literature were undertaken for the period 1993-2013. Papers were included if participants were between 18 and 65 years old, and study designs were either pre-test posttest one group descriptive, non-randomised group comparison, or randomised controlled trial, with reported data appropriate for meta-analysis and sufficient for estimating effect size(s). Total 19 studies were eligible in the meta-analysis, and 2,986 participants were examined. Six general outcome categories emerged from the data: (1) psychosocial functioning, (2) self-efficacy, (3) quality of life, (4) health status, (5) health behaviours and (6) health care use. In total, 155 effect sizes were calculated from the outcome measures with $15.5 \%$ resulting in a large effect size, $6 \%$ moderate effects, $39 \%$ small effects, and $39.5 \%$ producing trivial effects. The majority of the effect sizes (92\%) were in the hypothesised direction. Overall, results demonstrate that self-help and support group interventions can positively influence management of chronic ill-health conditions and contribute to the desired outcome of successful adaptation.
\end{abstract}

Keywords: support group, disability, rehabilitation

Social support has been well documented as an important contributor to human health or bio-psycho-social well-being. It is increasingly identified as having a powerful influence on return to work outcomes (Murphy \& O'Hare, 2016). For this reason, rehabilitation counsellors and occupational rehabilitation services have progressively implemented social support into their rehabilitation service plans (Katz et al., 2005).

Social support is a multidimensional construct, whereby the intent or purpose is information sharing and exchange, emotional support and sharing of experiences (Krause, 2003). These processes may ameliorate the consequences of chronic conditions by enhancing recovery, increasing adherence to treatment

Address for correspondence: Professor Gregory Murphy, La Trobe University, Faculty of Public Health, Bundoora Campus, VIC 3086.E-mail: G.Murphy@latrobe.edu.au 
recommendations and promoting overall psychological adaptation (Hill, Weinert, \& Schillo, 2004).

Various types of social support group interventions have been identified and are increasingly featured in health care strategies in an attempt to care cost effectively for expanding populations with chronic conditions (Foster, Taylor, Eldridge, Ramsay, \& Griffiths, 2009). For example, within the chronic disease management and occupational rehabilitation literature, 'self-help' or 'support groups', 'peer-support groups' and 'self-management education groups'are among the most commonly identified types of social support group interventions. They are offered through a number of different modes of delivery including face-to-face group support, telephone or computer-based online group support. Although the primary aim of each of these interventions is to provide social support to people living with chronic ill-health conditions, slight variations exist between each intervention type.

One main differentiating feature is whether the groups are led by an 'expert professional' or a 'lay-person'. Social support group interventions may also vary widely in their goals, for example from very general goals such as 'emotional support' for parents who have lost an infant, to very specific goals such as return to pre-injury position at work in groups for those off work for major injury. Perhaps the most important characteristic that differentiates social support groups is the extent to which they are based on valid theory or previous empirical support.

Research suggests that 'self-help' or 'support groups' may promote universality, hope, interpersonal learning or therapeutic change (Hill, Weinert, \& Cudney, 2006). Self-help or support groups are described in the literature as voluntary, small groups, designed for the mutual help and fulfilment of a common purpose, or for overcoming or mitigating a shared problem or condition that alters the normal course of life or for achieving a social change regarding the shared problem (Hill et al., 2006).

In occupational rehabilitation, self-help or support groups are typically led by approved allied health professionals, although in other contexts genuine self-help or support groups led by lay leaders who may have also experienced a chronic condition have achieved some success. A typical self-help or support group in occupational rehabilitation would be one for chronic pain management or job finding.

A distinction is also made in the literature between peer-support groups and self-management education groups, which identify the former as less formalised (Foster et al., 2009). The content of peer-support groups is not usually programmed in advance, whereas self-management education groups generally have a well-defined and pre-determined structure, and peer support may be a component of some selfmanagement education group programmes (Foster et al., 2009). Self-management education group programmes, such as the Chronic Disease Self-Management Program developed at Stanford University, are usually based on theoretical models such as Bandura's self-efficacy theory (Foster et al., 2009). In this model, successful behaviour change is linked with the person's confidence or belief in their ability to carry out an action and expectation that their particular goal will be achieved (Lorig, Ritter, $\&$ Jacquez, 2005). Self-management education group programmes are also distinct from simple patient education or skills training, as they are designed to allow people with chronic conditions to take an active part in the management of their own condition. 
The available research indicates that self-management education groups for chronic conditions have perhaps the strongest claims for being replicated; they could be usefully employed within service plans for work-injured clients (Lorig \& Holman, 2003). For example, for chronic pain clients whose pain-catastrophising and activity-avoidance problems present major barriers to return-to-work planning. However, there are still gaps in our knowledge regarding strategies and there is a need for greater understanding and data regarding whom social support group interventions most benefit, and at what costs (Handley, Shumway, \& Schillinger, 2008). In particular, within major scientific journals devoted to rehabilitation, in general, and to occupational rehabilitation specifically, methodologies such as "job-finding groups" (Jones \& Azrin, 1973) have been surprisingly neglected. In Australasia, for example, return to work rates struggle to surpass $70 \%$ and durable return-to-work rates are even lower (see Social Research Centre, 2016).

Evidently, health outcome data are not gathered worldwide with common definitions and measurements, making it difficult to evaluate the effectiveness of these interventions across different cultural contexts. Also, it is important to measure the value of the range of interventions that are being implemented (e.g., telephone or computer-assisted outreach).

A systematic review and meta-analysis is both timely and important for (a) summarising existing research, (b) directing further investigation as well as (c) assisting in decision making of managed services. This investigation aimed to provide answers to questions about the outcomes to be expected from the use of social support group interventions in rehabilitation by examining the research assessing the effectiveness of the various social support group interventions offered to people living with chronic conditions.

\section{Method}

\section{Search Protocol}

The search of the published literature was undertaken using three electronic databases: CINAHL (Cumulative Index to Nursing and Allied Health Literature), MEDLINE and PsychINFO for the period 1993-2013. Different combinations of the following keywords were used: ['support group*' or 'self-help group*' or 'peer-support group' or 'group psychosocial support'] and ['chronic disease*' or 'chronic illness*' or 'physical illness' or 'injury'].

\section{Paper Inclusion and Exclusion Criteria}

In the selection process, papers were included if they met the following inclusion criteria: (1) written in English; (2) peer reviewed journal article; (3) study participants were aged between 18 and 65 years; (4) investigated the effectiveness or effect(s) of support groups; (5) described a specific programme where a health professional or trained lay leader conducted or facilitated a support group for people with chronic disease or physical illness (e.g., diabetes, cancer, multiple sclerosis or rheumatoid condition) or injury (e.g., acquired brain injury, spinal cord injury); (6) study participants in the support group had been diagnosed or treated for chronic disease or physical illness or injury; (7) primary purpose of the support group was to provide support to 


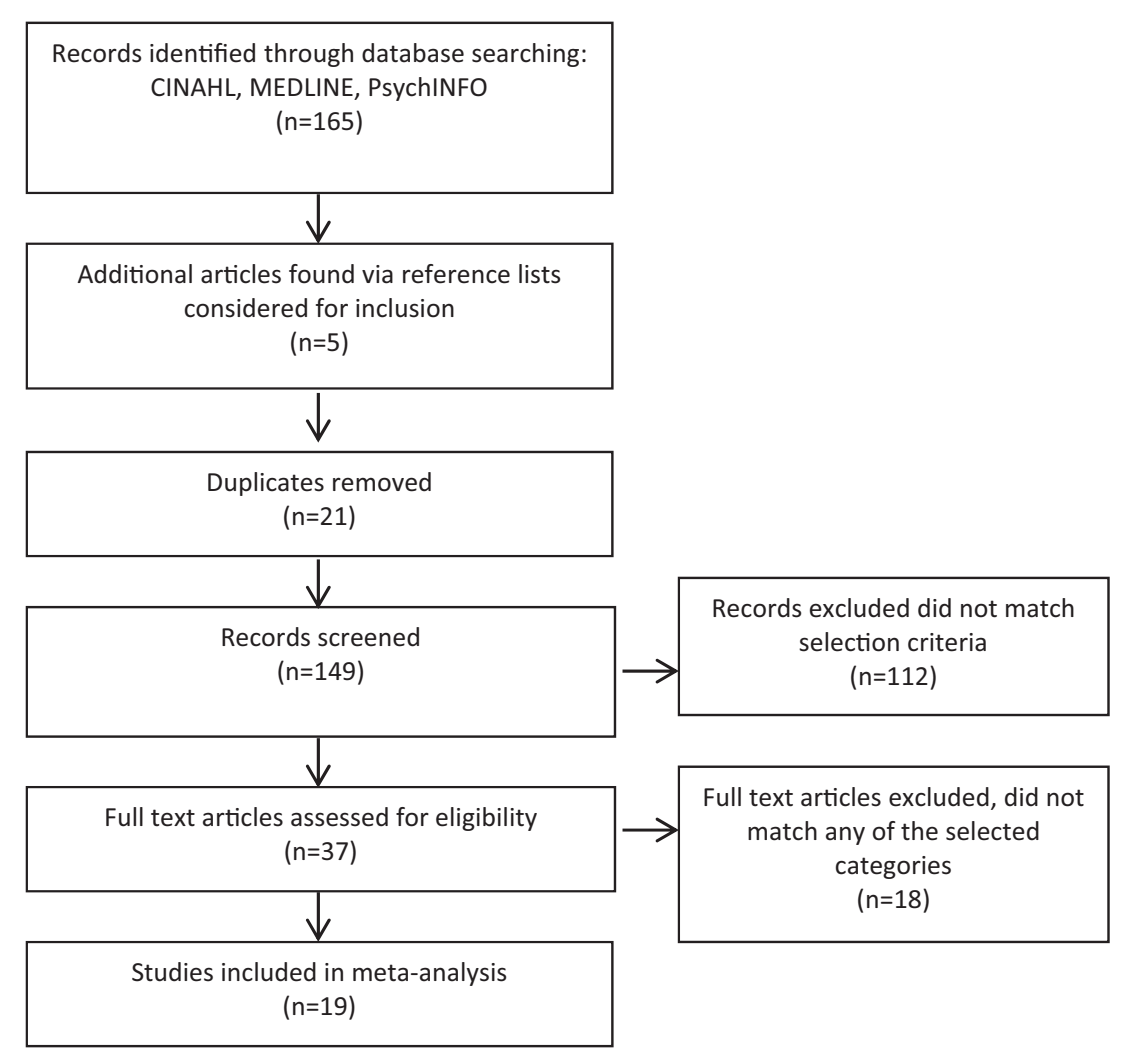

\section{FIGURE 1}

Process of inclusion of studies in the meta-analytic review.

patients with chronic disease or physical illness or injury and (8) study design included validated continuous or dichotomous measures at both pre- and post-intervention or by group comparison (e.g., intervention vs. control) with reported data sufficient for estimating effect size(s). Papers were excluded if: (1) they were not a specific support group programme; (2) they focused on children or adolescents or elderly (65+ years); (3) the support group was for someone other than the person with the chronic disease or physical illness or injury (e.g., carer or friend); (4) the paper did not describe the programme in sufficient details; (5) how the health professional or trained lay leader conducted or facilitated the support group that could not be determined; (6) it was unclear if the person who conducted or facilitated the support group was a health professional or trained lay leader; (7) it was an editorial or letter about a programme and (8) it was a first-person account of an experience.

\section{Paper Selection}

After the search protocol was conducted, the abstracts were examined for their applicability according to the selection criteria (Figure 1). When the information in an 
abstract was not sufficient in order to categorise the paper, the full text of the papers was retrieved for reading. All papers that appeared eligible were examined further by Author A, and then categorised as: 'eligible', 'not eligible' or 'borderline'. The categorised papers were then examined independently by Author B. The researchers discussed papers considered 'borderline' for inclusion until consensus was reached. If two papers presented the same dataset with no new information supplied, only the earlier paper was retained.

Selected papers were classified into one of the following categories: pre-test posttest one group descriptive studies (i.e., no control group, describing a programme with data collection pre- and post-intervention, one group only and no experimental design); non-randomised comparative studies and randomised controlled trials. Data were extracted from eligible papers about the main characteristics of the social support group programme (e.g., mode of delivery, diagnosis, type of social support group and information about the support recipients) as well as details of the research (e.g., sample size, outcome measures and outcome data).

\section{Data Analysis}

Effect size was measured using the standardised mean difference $d$ (Cohen, 1988) and each measure was represented by one effect size value. The magnitude of effect sizes was interpreted as a small effect $(d=0.2)$, a moderate or medium-sized effect $(d=0.5)$ and a large effect $(d=0.8)$. Transformation formulae for different statistical coefficients such as correlations and t-values were used (Lipsey \& Wilson, 2001; Rosenthal, 1994; Wolf, 1986). This type of analysis makes the following critical assumptions: the data are normally distributed (assumption of normality); there is homogeneity of variance (homoscedasticity) - effect size is sensitive to the heterogeneity of variance of differing variances (heteroscedasticity) and that there is reliability of measures.

\section{Results}

The searches yielded 165 unique published papers, and an additional five papers were found via searching references lists, producing a final count of 170 . Twenty-one duplicates were removed and a further 112 papers clearly irrelevant (for example, they focused on children or adolescents or were not a specific support group intervention) were eliminated. The remaining 37 papers were further investigated for eligibility according to the inclusion criteria, and of these, 19 studies were eligible for inclusion in the meta-analysis. The studies originated from nine different countries including: USA (7), Australia (3), England (3), New Zealand (1), Taiwan (1), Norway (1), Mexico (1), Sweden (1) and Chile (1). Altogether a total of 2,986 participants were examined in these studies.

Overall, the most common outcome measures employed were related to psychosocial functioning (e.g., depression, stress and coping). Further examination of the studies revealed that six outcome categories (as commonly agreed by two of the current authors, $A B$ and $G M$ ) emerged from the data: (a) psychosocial functioning (e.g., emotion regulation, self-esteem and social support), (b) self-efficacy, (c) quality of life, (d) health status (e.g., pain reduction and stress management), (e) health behaviours (e.g., physical activity, diet and communication with physician) and (f) health care 
use (e.g., hospital visits). In total, 155 effect sizes were calculated from the outcome measures used; $15.5 \%$ (24) resulted in a large effect size, $6 \%$ (10) resulted in a moderate effect size, 39\% (60) resulted in a small effect size and 39.50\% (61) produced trivial effects, resulting in Cohen's $d$ of less than 0.20 .

\section{Injury, Chronic Disease and Pain - Group Descriptive Studies}

Eight pre-test post-test one-group descriptive study designs were identified and included in the meta-analysis. A total of 627 participants were involved in these studies (see Table 1 for a complete listing). Three studies were conducted with non-English speaking participants (Spanish and Chinese) (Armengol, 1999; Chen, Pai, \& Li, 2008; Lorig et al., 2005). The most common diagnosis among the study participants was brain injury (e.g., traumatic or acquired) and chronic disease (e.g., cancer, diabetes, kidney, heart or lung disease), followed by chronic pain (e.g., musculoskeletal pain and fibromyalgia). All except one study, which was conducted online among women only (Lieberman et al., 2003), involved a group face-to-face support intervention involving both men and women. Of the eight studies, four employed a health professional to facilitate the support group intervention, and three employed a trained lay leader, and one study employed both. One study (Muenchberger, Kendall, Kennedy, \& Charker, 2011) that examined participants with a diagnosis of acquired brain injury and their response to a support group intervention, found the results were gender sensitive, and that females did not appear to benefit in goal commitment and self-management. This finding is further addressed in the discussion section of this review. A summary of the characteristics of each study is provided in Table 1, together with the median effect size from each study (see the last column in Table 1).

Overall, 31\% (23) of the outcome measures used resulted in a large effect size; however, many of the confidence intervals were wide in range, indicating higher levels of uncertainty in the precision of the effect size estimate. Of these measures, $74 \%$ (17) demonstrated an increase in positive outcomes, ranging from 0.90 to 2.72 , including coping, emotional control, self-regulation, quality of life and psychosocial functioning. Twenty-two per cent (5) of the measures showed a decrease in negative outcomes, including depression, hopelessness, stress and physical pain, ranging from -3.17 to -0.80 . Four per cent (1) of the measures produced an unexpected larger effect size $(d=-0.91)$ in the opposite direction to what was predicted showing a decline in coping behaviour for females (Muenchberger et al., 2011).

A further $8 \%$ (6) of the outcome measures resulted in a moderate effect size. Of these measures, $33 \%$ (2) demonstrated an increase in positive outcomes, ranging from 0.59 to 0.61 , including self-efficacy and mental stress management. Fifty per cent (3) of the measures showed a decrease in negative outcomes, including pain and health distress, ranging from -0.64 to -0.55 , whereas $17 \%$ (1) produced a moderate effect $(d=-0.50)$ in the opposite direction to what was predicted for females, showing a decline in goal commitment (Muenchberger et al., 2011).

Twenty-eight per cent (21) of the outcome measures resulted in a smaller effect size, with $48 \%$ (10) of these measures showing an increase in positive outcomes, ranging from 0.21 to 0.41 , including self-efficacy, stress management and health behaviours (e.g., diet, exercise and communication with physician). A further $48 \%$ (10) of these measures showed a decrease in negative outcomes, ranging from 


\begin{tabular}{|c|c|c|c|c|c|c|c|c|c|}
\hline \multicolumn{10}{|c|}{$\begin{array}{l}\text { TABLE } 1 \\
\text { Characteristics of Pre-Test Post-Test One Group Descriptive Studies }(N=8)\end{array}$} \\
\hline $\begin{array}{l}\text { Author, } \\
\text { year }\end{array}$ & $\begin{array}{l}\text { Participant } \\
(N)\end{array}$ & Diagnosis & $\begin{array}{l}\text { Country } \\
\text { of } \\
\text { study }\end{array}$ & $\begin{array}{l}\text { Intervention } \\
\text { type }\end{array}$ & Program & Method & Leader & Outcome measures & $\begin{array}{l}\text { Median } \\
\text { effect size }\end{array}$ \\
\hline $\begin{array}{r}\text { Armengol } \\
\text { (1999) }\end{array}$ & 6 & $\begin{array}{l}\text { Traumatic } \\
\text { brain injury }\end{array}$ & USA & $\begin{array}{r}\text { Support } \\
\text { group }\end{array}$ & $\begin{array}{l}10 \text { weeks/ } \\
\text { once a } \\
\text { week/ } \\
2.5 \\
\text { hours }\end{array}$ & $\begin{array}{l}\text { Group } \\
\text { face } \\
\text { to } \\
\text { face }\end{array}$ & $\begin{array}{l}\text { Health } \\
\text { profes- } \\
\text { sional }\end{array}$ & $\begin{array}{l}\text { Beck Hopelessness Scale } \\
\text { (BHS); Purpose in Life Test } \\
\text { (PIL); Perceived } \\
\text { Self-Regulatory Ability } \\
\text { Inventory (PSRA) }\end{array}$ & 2.28 \\
\hline $\begin{array}{l}\text { Arthur } \\
\text { and Ed- } \\
\text { wards } \\
(2005)\end{array}$ & 43 & Chronic pain & England & $\begin{array}{l}\text { Self-help } \\
\text { group }\end{array}$ & $\begin{array}{l}10 \text { weeks/ } \\
\text { once a } \\
\text { week/ } \\
2 \text { hours }\end{array}$ & $\begin{array}{l}\text { Group } \\
\text { face } \\
\text { to } \\
\text { face }\end{array}$ & $\begin{array}{l}\text { Health } \\
\text { profes- } \\
\text { sional }\end{array}$ & $\begin{array}{l}\text { Pain Stages of Change } \\
\text { Questionnaire (PSOCQ: } \\
\text { pre-contemplation, } \\
\text { contemplation, action, } \\
\text { maintenance); Hospital } \\
\text { Anxiety Depression Scale } \\
\text { (HADS); Roland Morris } \\
\text { Disability Questionnaire } \\
\text { (RMDQ-A) }\end{array}$ & 0.15 \\
\hline $\begin{array}{l}\text { Chen } \\
\text { et al. } \\
\text { (2008) }\end{array}$ & 15 & $\begin{array}{l}\text { End stage } \\
\text { renal } \\
\text { disease }\end{array}$ & Taiwan & $\begin{array}{l}\text { Mutual-help } \\
\text { group }\end{array}$ & $\begin{array}{l}3 \text { months/ } \\
8 \text { fort- } \\
\text { nightly } \\
\text { ses- } \\
\text { sions/ } \\
2 \text { hours }\end{array}$ & $\begin{array}{l}\text { Group } \\
\text { face } \\
\text { to } \\
\text { face }\end{array}$ & $\begin{array}{l}\text { Health } \\
\text { profes- } \\
\text { sional }\end{array}$ & $\begin{array}{l}\text { Physical Symptoms Scale } \\
\text { (PSS); Social Support } \\
\text { Scale (SSS) Quality of Life } \\
\text { Scale (QoLS) }\end{array}$ & 1.76 \\
\hline
\end{tabular}




\begin{tabular}{|c|c|c|c|c|c|c|c|c|c|c|}
\hline \multirow{3}{*}{ 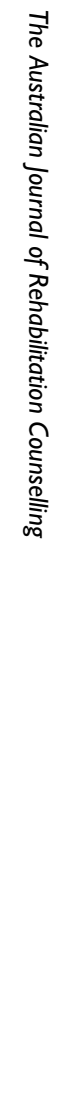 } & \multicolumn{10}{|l|}{$\begin{array}{l}\text { TABLE } 1 \\
\text { Continued }\end{array}$} \\
\hline & $\begin{array}{l}\text { Author, } \\
\text { year }\end{array}$ & $\begin{array}{l}\text { Participant } \\
(N)\end{array}$ & Diagnosis & $\begin{array}{l}\text { Country } \\
\text { of study }\end{array}$ & $\begin{array}{l}\text { Intervention } \\
\text { type }\end{array}$ & Program & Method & Leader & Outcome measures & $\begin{array}{l}\text { Median } \\
\text { effect size }\end{array}$ \\
\hline & $\begin{array}{l}\text { Lieberman } \\
\text { et al. } \\
\text { (2003) }\end{array}$ & 32 & $\begin{array}{l}\text { Breast } \\
\text { carcinoma }\end{array}$ & USA & $\begin{array}{l}\text { Real-time } \\
\text { electronic } \\
\text { support } \\
\text { group }\end{array}$ & $\begin{array}{l}16 \text { weeks/ } \\
\text { weekly } \\
\text { meet- } \\
\text { ings/ } \\
1.5 \text { hour } \\
\text { session }\end{array}$ & $\begin{array}{l}\text { Online } \\
\text { group }\end{array}$ & $\begin{array}{c}\text { Trained } \\
\text { lay- } \\
\text { leader }\end{array}$ & $\begin{array}{l}\text { Centre for Epidemiologic } \\
\text { Studies-Depression Scale } \\
\text { (CES-D) (Depression and } \\
\text { Coping); Courtauld } \\
\text { Emotional Control Scale } \\
\text { (CECS); Posttraumatic } \\
\text { Growth Inventory (PTGI) } \\
\text { (Relating, New } \\
\text { Possibilities, Personal } \\
\text { Strength, Spiritual, } \\
\text { Appreciation); Pain } \\
\text { Self-rating scale } \\
\text { (Interferes, Intensity, } \\
\text { Reaction); Personality } \\
\text { traits: the Weinberger } \\
\text { Adjustment Inventory } \\
\text { (WAI) (distress, restraint \& } \\
\text { defensiveness) (pre-test } \\
\text { only) }\end{array}$ & 0.90 \\
\hline
\end{tabular}


TABLE 1

Continued

\begin{tabular}{|c|c|c|c|c|c|c|c|c|c|}
\hline $\begin{array}{l}\text { Author, } \\
\text { year }\end{array}$ & $\begin{array}{l}\text { Participant } \\
\text { (N) }\end{array}$ & Diagnosis & $\begin{array}{l}\text { Country } \\
\text { of study }\end{array}$ & $\begin{array}{l}\text { Intervention } \\
\text { type }\end{array}$ & Program & Method & Leader & Outcome measures & $\begin{array}{l}\text { Median } \\
\text { effect size }\end{array}$ \\
\hline $\begin{array}{l}\text { Lorig et al. } \\
\text { (2005) }\end{array}$ & 445 & $\begin{array}{l}\text { Chronic } \\
\text { disease } \\
\text { (e.g., } \\
\text { diabetes, } \\
\text { heart } \\
\text { disease, } \\
\text { lung } \\
\text { disease) }\end{array}$ & Mexico & $\begin{array}{l}\text { Chronic } \\
\text { disease self- } \\
\text { management } \\
\text { programme }\end{array}$ & $\begin{array}{c}6 \text { weeks/ } \\
\text { once a } \\
\text { week/ } \\
2.5 \\
\text { hours }\end{array}$ & $\begin{array}{l}\text { Group } \\
\text { face } \\
\text { to } \\
\text { face }\end{array}$ & $\begin{array}{l}\text { Trained } \\
\text { lay- } \\
\text { leaders }\end{array}$ & $\begin{array}{l}\text { Health behaviours (physical } \\
\text { activity, mental stress } \\
\text { management, diet, } \\
\text { communication with } \\
\text { physician); Health status } \\
\text { (pain, shortness of breath, } \\
\text { fatigue, health distress, } \\
\text { activity limitation, } \\
\text { self-reported health); } \\
\text { Self-efficacy scale; Health } \\
\text { care use (visits to } \\
\text { physicians, ER visits, days } \\
\text { in hospital over last } \\
4 \text { months) }\end{array}$ & 0.24 \\
\hline $\begin{array}{l}\text { Muenchberger } \\
\text { et al. } \\
\text { (2011). }\end{array}$ & 52 & $\begin{array}{l}\text { Acquired } \\
\text { brain injury }\end{array}$ & Australia & $\begin{array}{l}\text { Group } \\
\text { support } \\
\text { programme }\end{array}$ & $\begin{array}{l}6 \text { weeks/ } \\
\text { once a } \\
\text { week/ } \\
\text { length of } \\
\text { sessions } \\
\text { not } \\
\text { specified }\end{array}$ & $\begin{array}{l}\text { Group } \\
\text { face } \\
\text { to } \\
\text { face }\end{array}$ & $\begin{array}{l}\text { Trained } \\
\text { lay- } \\
\text { leader } \\
\text { or } \\
\text { health } \\
\text { profes- } \\
\text { sional }\end{array}$ & $\begin{array}{l}\text { Depression Anxiety Stress } \\
\text { Scales (DASS-21); Goal } \\
\text { commitment index; Active } \\
\text { Coping Scale } \\
\text { (self-management); } \\
\text { Self-efficacy scale; } \\
\text { General health (RAND); }\end{array}$ & $\begin{array}{l}0.15 \\
\text { males } \\
0.50 \\
\text { females }\end{array}$ \\
\hline
\end{tabular}




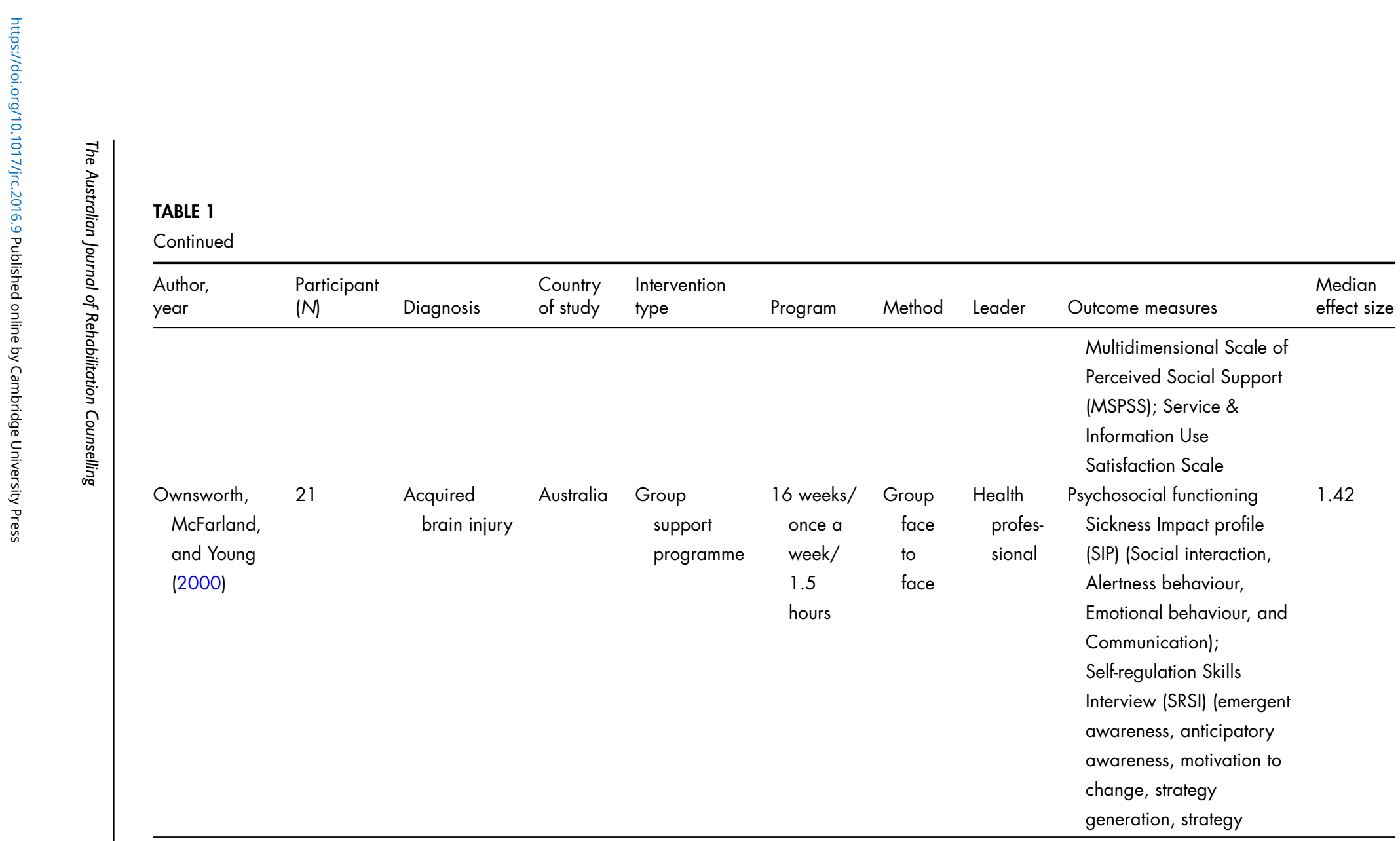


TABLE 1

Continued

\begin{tabular}{|c|c|c|c|c|c|c|c|c|c|}
\hline $\begin{array}{l}\text { Author, } \\
\text { year }\end{array}$ & $\begin{array}{l}\text { Participant } \\
(N)\end{array}$ & Diagnosis & $\begin{array}{l}\text { Country } \\
\text { of study }\end{array}$ & $\begin{array}{l}\text { Intervention } \\
\text { type }\end{array}$ & Program & Method & Leader & Outcome measures & $\begin{array}{l}\text { Median } \\
\text { effect size }\end{array}$ \\
\hline & & & & & & & & $\begin{array}{l}\text { selection, effectiveness of } \\
\text { strategies); Head Injury } \\
\text { Behaviour Scale (HIBS) } \\
\text { (self-report and } \\
\text { family/relative report); } \\
\text { Self-Awareness Deficits } \\
\text { Interview (SADI) }\end{array}$ & \\
\hline $\begin{array}{l}\text { Subramaniam } \\
\text { et al. (1999) }\end{array}$ & 13 & $\begin{array}{c}\text { Chronic pain } \\
\text { (predomi- } \\
\text { nantly low } \\
\text { back pain) }\end{array}$ & $\begin{array}{l}\text { New } \\
\text { Zealand }\end{array}$ & $\begin{array}{l}\text { Self-help } \\
\text { support } \\
\text { group }\end{array}$ & $\begin{array}{c}5 \text { months/ } \\
\text { once a } \\
\text { month/ } \\
2 \text { hours }\end{array}$ & $\begin{array}{l}\text { Group } \\
\text { face } \\
\text { to } \\
\text { face }\end{array}$ & $\begin{array}{l}\text { Trained } \\
\text { lay- } \\
\text { leader }\end{array}$ & $\begin{array}{l}\text { Multidimensional Pain } \\
\text { Inventory (MPI) (functional } \\
\text { disability, affective } \\
\text { distress, supportive } \\
\text { interactions, pain-sensory } \\
\text { evaluation, pain-affective } \\
\text { response) }\end{array}$ & 0.14 \\
\hline
\end{tabular}


-0.44 to -0.21 , including pain and health distress. Four per cent (1) of measures produced a smaller effect size $(-0.38)$ in the opposite direction to what was predicted for females, identifying a decline in self-reported levels of personal strength.

Thirty-three per cent (25) of the outcome measures of these studies produced trivial effects, resulting in Cohen's $d$ of less than 0.20 . Of these measures, $48 \%$ (12) showed a decline in negative outcomes (Cohen's $d$ ranging -0.19 to -0.02 ) including depression, anxiety and physical distress, whereas 32\% (8) of the measures showed an increase in positive outcomes (Cohen's $d$ ranging from 0.01 to 0.19 ) including motivation to change and health behaviours (e.g., communication with physician). Sixteen per cent (4) of the measures produced trivial effects in the opposite direction to what was predicted, showing a slight increase in stress and healthcare use, and $4 \%$ (1) of the measures produced no mean change or effect size $(d=0)$ in relation to healthcare use (emergency visits).

\section{Quality of Life - Non-Randomised Comparative Studies}

Two non-randomised comparison group study designs were identified and included in the meta-analysis. Overall, 60 participants were examined in these studies and were conducted in different countries (Australia and Chile) (Krause, 2003; Thomas, 2004). The outcome measures produced small to moderate effects on average. Both studies used quality of life as the main outcome measure and employed health professionals to facilitate the social support group interventions. Each study differed with regard to participants' diagnosis (ulcerative bowl disease and acquired brain injury respectively) and differed slightly in their social support group intervention approaches. For instance, though both studies facilitated regular group meetings, one of the studies (Thomas, 2004) incorporated an experiential component to the programme in which participants were required to take part in outdoor group adventure activities as part of their learning. This study also employed a longitudinal design, measuring progress at five different time points (Time 1 - baseline; Time 2 - after completion of stage 2 of programme; Time 3 - post-programme; Time $4-6$ months' post-programme; Time $5-2$ years post-programme) and found significant change in outcomes at 6 months' post-programme between groups, resulting in a larger effect size $(d=2.03)$. Although these changes were not found to be significantly different at the 2-year measurement interval post-programme, the effect size was moderate $(d=0.68)$. Trivial to small effects were also found at time points 1 and 3 for quality of life in the opposite direction to what was predicted, with mean scores slightly lower for the experimental group compared to the control group. A summary of the characteristics of each study is provided in Table 2 .

The second study by Krause (2003) involved participants in a year-long self-help programme and included a knowledge comparison measure in addition to quality of life measures. Two of the outcome variables produced moderate effects with regard to decreased negative outcomes including emotional and physical distress, ranging from -0.47 to -0.63 , whereas one of the outcome variables produced trivial effects with regard to social improvement $(d=0.13)$. No significant difference was found between groups for the knowledge comparison measure; however, a significant improvement in knowledge of illness was found for the experimental group post-intervention. 


\begin{tabular}{|c|c|c|c|c|c|c|c|c|c|}
\hline $\begin{array}{l}\text { Author, } \\
\text { year }\end{array}$ & $\begin{array}{l}\text { Participant } \\
\text { (N) }\end{array}$ & Diagnosis & $\begin{array}{l}\text { Country of } \\
\text { study }\end{array}$ & $\begin{array}{l}\text { Intervention } \\
\text { type }\end{array}$ & Program & Method & Leader & Outcome measures & $\begin{array}{l}\text { Median } \\
\text { effect size }\end{array}$ \\
\hline
\end{tabular}




\section{Chronic Disease and Brain Injury - Randomised Controlled Trial Studies}

Nine randomised controlled trial studies were identified and included in the exploratory meta-analysis. Overall a total of 2,229 participants were examined in these studies. A summary of the characteristics of each study is provided in Table 3. The majority of these studies were conducted in the USA (5), followed by European countries (4).

Overall, the most common diagnosis among this group of studies was chronic disease (e.g., diabetes, heart and lung disease and cancer), followed by chronic pain (e.g., back pain, fibromyalgia) and acquired brain injury. Three of the studies were conducted with participants speaking a language other than English (Bangladeshi, Norwegian and Swedish) (Griffiths et al., 2005; Haugli, Steen, Laerum, Nygard, \& Finset, 2001; Linton, Hellsing, \& Larsson, 1997). Two of the nine randomised controlled study designs employed health professionals to facilitate the support interventions, three were conducted by trained lay-leaders and four of the studies involved an online intervention utilising a health professional to monitor the online interaction between peers. The four studies that employed an online group intervention were conducted with women participants only $(N=884)$ and focused on providing support to women with various chronic ill-health conditions that lived in rural or remote locations (Hill et al., 2004, 2006; Weinert, Cudney, Comstock, \& Bansal, 2011; Weinert, Hill, \& Cudney, 2008). Of these four studies, one study (Hill et al., 2004) used perceived social support as the primary outcome measure and captured participants' responses at five time periods (baseline; $2-2.5$ months; $3-5$ months; 7.5 months; 10 months). This study found no statistically significant results for any measure and trivial effects on average; however, mean scores showed an increase over time in perceived social support for the intervention group. Of the remaining three studies that focused on women, the effect size was smaller on average, and most likely to be associated with improvements in psychosocial functioning (e.g., depression, stress, acceptance of illness and social support) and self-efficacy.

Three of the randomised control trial studies (Hill et al., 2004; Linton et al., 1997; Weinert et al., 2008) compared the effectiveness of the support intervention across three groups rather than two groups (i.e., control vs. intervention). In all three studies, the third group formed a less intense version of the intervention and was more focused on the facilitation of information or education and had either none or very little emphasis on social-support-related interactions among group members. Only one of these studies found a significant difference between groups for the outcome measures social support and self-efficacy (Weinert et al., 2008), whereas the other two studies found no significant differences between the three groups (Hill et al., 2004; Linton et al., 1997). Changes in mean scores over time, however, showed greater gains or improvement in the intervention group for perceived social support, pain reduction and sleep quality compared to the control group and the educational or less intense version of the intervention. For the purposes of this meta-analysis and to maintain consistency in the reporting of results, only effect sizes between the intervention and control groups were compared.

A total of 72 effect sizes was calculated from the outcome measures used in these studies. Overall, 3\% (2) of the outcome measures resulted in a moderate effect size 


\begin{tabular}{|c|c|c|c|c|c|c|c|c|c|}
\hline \multicolumn{10}{|c|}{$\begin{array}{l}\text { TABLE } 3 \\
\text { Characteristics of Randomised Controlled Trial Studies }(N=9)\end{array}$} \\
\hline $\begin{array}{l}\text { Griffiths } \\
\text { et al. } \\
\text { (2005) }\end{array}$ & 479 & $\begin{array}{c}\text { Diabetes } \\
(68 \%), \\
\text { asthma } \\
(17 \%), \\
\text { arthritis } \\
(10 \%), \\
\text { heart } \\
\text { disease } \\
(5 \%)\end{array}$ & England & $\begin{array}{l}\text { Chronic } \\
\text { Disease } \\
\text { Self- } \\
\text { Management } \\
\text { Program }\end{array}$ & $\begin{array}{c}6 \text { weeks/ } \\
\text { weekly } \\
\text { meet- } \\
\text { ings/ } \\
3 \text { hours } \\
\text { session }\end{array}$ & $\begin{array}{l}\text { Group } \\
\text { face } \\
\text { to } \\
\text { face }\end{array}$ & $\begin{array}{l}\text { Trained } \\
\text { lay- } \\
\text { leader }\end{array}$ & $\begin{array}{l}\text { Chronic Disease Self-Efficacy } \\
\text { Scale, Self-care behaviour, } \\
\text { Communication with } \\
\text { physician, Hospital } \\
\text { Anxiety Depression Scale } \\
\text { (HADS), Health status } \\
\text { (Pain, fatigue and } \\
\text { shortness of breath), } \\
\text { Quality of Life scale } \\
\text { (EuroQol EQ5D), Health } \\
\text { care use (Visits to } \\
\text { GP/Nurse in last } \\
3 \text { months) }\end{array}$ & 0.12 \\
\hline $\begin{array}{l}\text { Haugli } \\
\text { et al. } \\
\text { (2001) }\end{array}$ & 174 & $\begin{array}{l}\text { Chronic } \\
\text { musculo- } \\
\text { skeletal } \\
\text { pain (e.g., } \\
\text { figbromyal- } \\
\text { gia and } \\
\text { chronic } \\
\text { back pain) }\end{array}$ & Norway & $\begin{array}{l}\text { Group pain- } \\
\text { management } \\
\text { programme }\end{array}$ & $\begin{array}{l}9 \text { months/ } \\
12 \text { fort- } \\
\text { nightly } \\
\text { meet- } \\
\text { ings/ } \\
4 \text { hours }\end{array}$ & $\begin{array}{l}\text { Group } \\
\text { face } \\
\text { to } \\
\text { face }\end{array}$ & $\begin{array}{l}\text { Health } \\
\text { profes- } \\
\text { sional }\end{array}$ & $\begin{array}{l}\text { Pain Visual Analogue Scale, } \\
\text { Pain coping Visual } \\
\text { Analogue Scale, Coping } \\
\text { with Life Demands Visual } \\
\text { Analogue Scale, Days } \\
\text { Absent during last } \\
6 \text { months of intervention, } \\
\text { Health care consumption }\end{array}$ & 0.32 \\
\hline
\end{tabular}


TABLE 3

Continued

\begin{tabular}{|c|c|c|c|c|c|c|c|c|c|}
\hline $\begin{array}{l}\text { Author, } \\
\text { year }\end{array}$ & $\begin{array}{l}\text { Participant } \\
\text { (N) }\end{array}$ & Diagnosis & $\begin{array}{l}\text { Country } \\
\text { of study }\end{array}$ & $\begin{array}{l}\text { Intervention } \\
\text { type }\end{array}$ & Program & Method & Leader & Outcome measures & $\begin{array}{l}\text { Median } \\
\text { effect size }\end{array}$ \\
\hline $\begin{array}{l}\text { Hill } \\
\text { et al. } \\
\text { (2004) }\end{array}$ & 242 & $\begin{array}{l}\text { Chronic } \\
\text { illness (e.g., } \\
\text { cancer, } \\
\text { multiple } \\
\text { sclerosis, } \\
\text { diabetes } \\
\text { and fi- } \\
\text { bromyalgia) }\end{array}$ & USA & $\begin{array}{l}\text { Online/ } \\
\text { computer- } \\
\text { delivered } \\
\text { support } \\
\text { group } \\
\text { intervention }\end{array}$ & $\begin{array}{c}22 \text { weeks/ } \\
24 \text { hours } \\
\text { access/ } \\
\text { not } \\
\text { specified }\end{array}$ & $\begin{array}{l}\text { Online/ } \\
\text { computer- } \\
\text { based } \\
\text { group }\end{array}$ & $\begin{array}{l}\text { Peer-led, } \\
\text { moni- } \\
\text { tored } \\
\text { by } \\
\text { health } \\
\text { profes- } \\
\text { sional }\end{array}$ & $\begin{array}{l}\text { Social support measured by: } \\
\text { Personal Resource } \\
\text { Questionnaire (PRQ85) } \\
\text { and Psychosocial } \\
\text { Adjustment to Illness Scale } \\
\text { (PAIS) }\end{array}$ & 0.01 \\
\hline $\begin{array}{l}\text { Hill } \\
\text { et al. } \\
\text { (2006) }\end{array}$ & 100 & $\begin{array}{l}\text { Chronic } \\
\text { illness (e.g., } \\
\text { diabetes, } \\
\text { rheumatoid } \\
\text { condition, } \\
\text { heart } \\
\text { disease, } \\
\text { cancer or } \\
\text { multiple } \\
\text { sclerosis) }\end{array}$ & USA & $\begin{array}{l}\text { Online/ } \\
\text { computer- } \\
\text { delivered } \\
\text { support } \\
\text { group } \\
\text { intervention }\end{array}$ & $\begin{array}{l}22 \text { weeks/ } \\
24 \text { hours } \\
\text { ac- } \\
\text { cess/not } \\
\text { specified }\end{array}$ & $\begin{array}{l}\text { Online/ } \\
\text { computer- } \\
\text { based } \\
\text { group }\end{array}$ & $\begin{array}{l}\text { Peer-led, } \\
\text { moni- } \\
\text { tored } \\
\text { by } \\
\text { health } \\
\text { profes- } \\
\text { sional }\end{array}$ & $\begin{array}{l}\text { Social support (PRQ2000), } \\
\text { Self-esteem Scale (SES), } \\
\text { Modified Diabetes } \\
\text { Empowerment Scale, } \\
\text { Rosenberg Self Esteem } \\
\text { Scale, Diabetes } \\
\text { Empowerment Scale, } \\
\text { Social Support Scale, } \\
\text { Self-Efficacy Scale, } \\
\text { Perceived Stress Scale } \\
\text { (PSS), Center for } \\
\text { Epidemiological, Studies } \\
\text { Depression, Scale } \\
\text { (CES-D), UCLA Loneliness } \\
\text { Scale }\end{array}$ & 0.33 \\
\hline
\end{tabular}




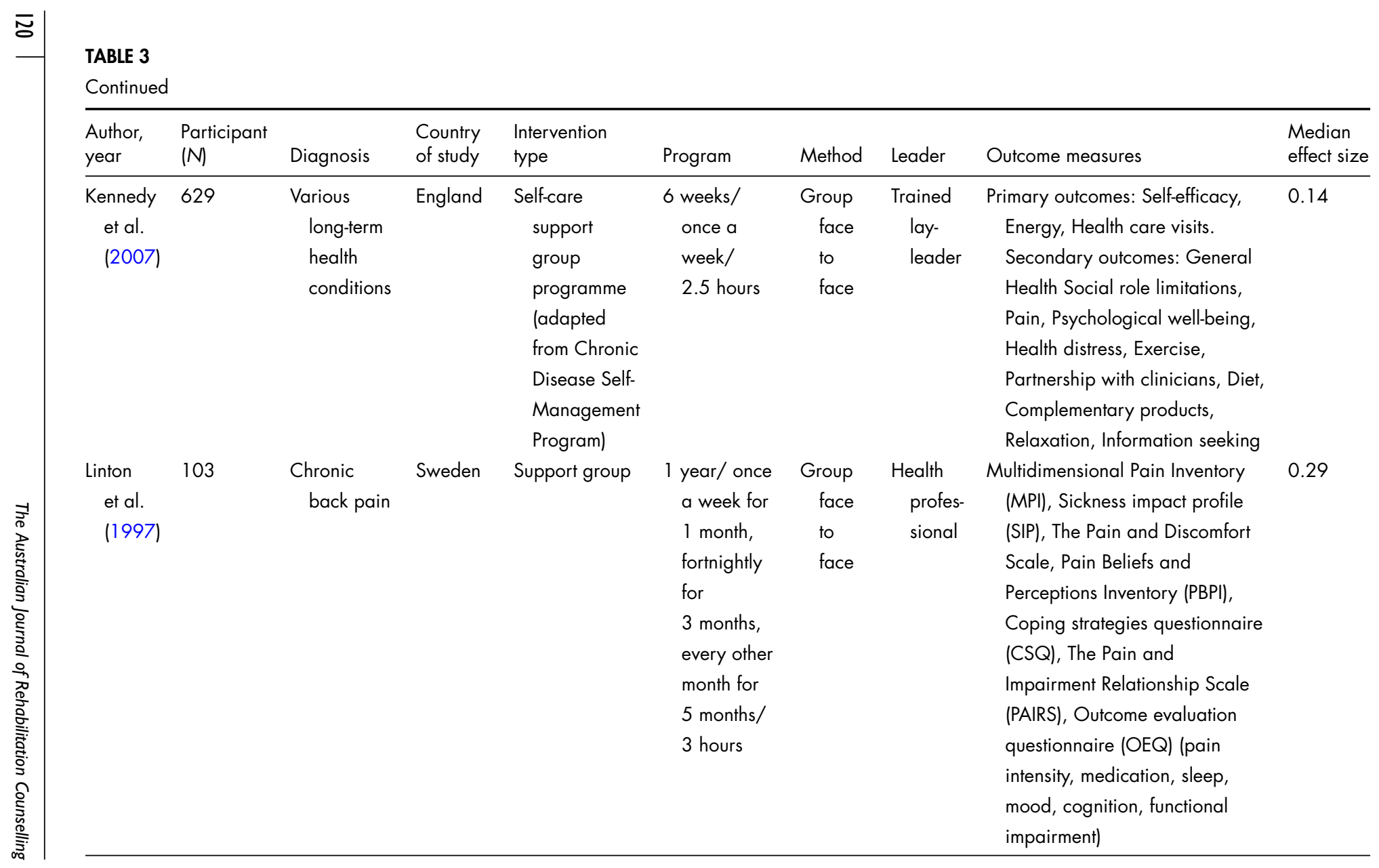


TABLE 3

Continued

\begin{tabular}{|c|c|c|c|c|c|c|c|c|c|}
\hline $\begin{array}{l}\text { Author, } \\
\text { year }\end{array}$ & $\begin{array}{l}\text { Participant } \\
(N)\end{array}$ & Diagnosis & $\begin{array}{l}\text { Country } \\
\text { of study }\end{array}$ & $\begin{array}{l}\text { Intervention } \\
\text { type }\end{array}$ & Program & Method & Leader & Outcome measures & $\begin{array}{l}\text { Median } \\
\text { effect size }\end{array}$ \\
\hline $\begin{array}{l}\text { Weinert } \\
\text { et al. } \\
(2008)\end{array}$ & 233 & $\begin{array}{l}\text { Various } \\
\text { chronic } \\
\text { illnesses }\end{array}$ & USA & $\begin{array}{l}\text { Online/ } \\
\text { computer- } \\
\text { delivered } \\
\text { support in- } \\
\text { tervention }\end{array}$ & $\begin{array}{l}22 \text { weeks/ } \\
24 \text { hour } \\
\text { access/ not } \\
\text { specified }\end{array}$ & $\begin{array}{l}\text { Online/ } \\
\text { computer- } \\
\text { based } \\
\text { group }\end{array}$ & $\begin{array}{l}\text { Peer-led, } \\
\text { moni- } \\
\text { tored } \\
\text { by } \\
\text { health } \\
\text { profes- } \\
\text { sional }\end{array}$ & $\begin{array}{l}\text { Personal Resource } \\
\text { Questionnaire, Rosenberg } \\
\text { Self-esteem scale, } \\
\text { Empowerment scale, } \\
\text { Self-efficacy scale, } \\
\text { Depression, Perceived stress } \\
\text { scale, UCLA loneliness scale }\end{array}$ & 0.23 \\
\hline
\end{tabular}


demonstrating a decrease in negative outcomes such as pain and discomfort, ranging from -0.53 to -0.50 . Fifty per cent (36) of the outcome measures resulted in a smaller effect size, and of these measures, $47 \%$ (17) showed a decrease in negative outcomes including pain, depression, stress, loneliness and days absent from work, ranging from -0.47 to -0.20 . Three per cent (1) of these measures resulted in effect sizes in the opposite direction to what was predicted for outcomes measuring health behaviour (e.g., partnership with clinician), showing a slight decrease $(d=$ -0.26). A further $47 \%$ (17) of these measures demonstrated an increase in positive outcomes, ranging from 0.22 to 0.49 , including self-efficacy, self-esteem, perceived social support, coping, self-care, empowerment and acceptance of illness. However, 3\% (1) of these measures showed a change in the opposite direction to what was predicted, showing a slight increase in depression post-intervention $(d=0.22)$ (Struchen et al., 2011).

A total of $47 \%$ (34) of all outcome measures from the randomised controlled trials resulted in trivial effect sizes, and of these measures, 44\% (15) showed a decrease in negative outcomes such as pain, loneliness and anxiety, ranging from -0.19 to -0.01 . However, $12 \%$ (4) of these measures showed a change in the opposite direction to what was predicted, showing a slight decrease in general health, social activity (i.e., in the past month and since injury) and satisfaction with life. A further $53 \%$ (18) of these outcome measures showed either no mean change (5) or resulted in an increase in positive outcomes (13) including psychological well-being, pain coping, quality of life, health behaviours (e.g., communication with physician), energy levels and relaxation.

\section{Discussion and Conclusions}

A total of 155 standardised effect sizes was calculated from the outcome measures identified in the 19 studies, and six general outcome categories emerged from the data: (a) psychosocial functioning (e.g., emotion regulation, self-esteem and social support), (b) self-efficacy, (c) quality of life, (d) health status (e.g., pain reduction, stress management), (e) health behaviours (e.g., physical activity, diet and communication with physician) and (f) health care use (e.g., hospital visits). The majority of outcome measures resulted in small $(39 \%)$ or trivial effects $(39.5 \%)$, and $21.5 \%$ resulted in a moderate to large effect sizes. The majority of the effect sizes $(92 \%)$ indicated a change in outcome scores in the hypothesised direction, whereas a small percentage $(8 \%)$ of effect sizes indicated a change in outcome scores in the opposite direction to what was predicted.

A number of randomised controlled trials exploring group Internet support group programmes were associated with improved psychosocial outcomes; however, it is not possible to determine whether these psychosocial benefits are related to the group Internet format per se or to some other factor. One possible factor influencing this is that these programmes often involved an asynchronous format (i.e., people logged on to read and post-messages at any time), and perhaps such flexibility is beneficial, enabling people to access support when needed, rather than waiting until scheduled meeting times like face to face programmes. These programmes also went for a longer period of time (from 12 to 24 weeks) than other support group programmes 
tested in the randomised controlled trials. Longer duration of support group contact may be required for people to develop relationships and build sufficient rapport to enable them to gain psychosocial benefits. In addition, a small number of longitudinal studies also found the health outcomes of support group interventions that were significant at 6 months, did not appear to be significant beyond 1 year. This finding emphasises the need for self-regulation skills for ongoing maintenance of the gains observed.

Overall, the magnitude of effect was broad as they were detected on a wide range of mental and physical health indicators. However, effects were found to be larger for studies employing a pre-test post-test one group descriptive design than for those employing a non-randomised comparative study design or randomised control trial study design that found smaller effects and had a greater percentage of outcome measure assessments that may suggest minimal group effectiveness. Smaller effects were found for self-efficacy and health behaviours such as physical activity and diet, whereas trivial effects were more commonly found for health care use. Effects were larger for the outcome categories health status, quality of life and psychosocial functioning, particularly with regard to pain management and/or reduction in pain symptoms, and emotional functioning (e.g., reduction in depressive symptoms and feelings of hopelessness). The confidence intervals were generally wider in range, however, suggesting some uncertainty in the precision of the effect size estimate. In addition, these outcome categories also produced both smaller as well as trivial effects across the range of studies, suggesting that the study designs and methodology were factors that may have influenced the consistency of results.

Trivial effects found may have been a result of methodological problems or it may suggest that the outcome measures utilised in these studies were not appropriate for assessing the effectiveness of the social support group interventions. Health outcome data also did not appear to be consistently gathered with common definitions and measurements. This suggests that research in this area would need to evaluate social support group interventions in terms of outcomes that match the aims of the intervention and the experiences of the participants, and then determine whether these outcomes are related to change in clinically relevant endpoints or outcomes relating to, for example, psychosocial functioning or quality of life.

Although the present meta-analysis provided initial answers to a number of questions about the effectiveness of the groups involved, there are areas that need further investigation, particularly with regard to potential moderator effects, such as culture, minority status and gender. For instance, one study (Muenchberger et al., 2011) showed differences in effect sizes between men and women, with females demonstrating a consistent decline in self-management over time, whereas males demonstrated a slight increase followed by a plateau. Although it is unknown exactly why this difference in gender emerged, one such explanation suggested in the research is the possibility of a response shift as a result of the programme (Muenchberger et al., 2011; Osborne, Hawkins, \& Sprangers, 2006). Females entered the programme with higher perceived self-management than males, but eventually declined to a lower level. Hence, the phenomenon of response shift suggests that it was a potentially desirable outcome reflecting the fact that the programme raised participants' awareness of the areas where they could better manage their own condition (Osborne et al., 
2006). Thus, pre-intervention self-reported ratings of self-management were likely to be inflated (predominantly due to lack of awareness) (Muenchberger et al., 2011). However, during the programme, increasing levels of awareness may have facilitated reduced levels of self-reported self-management. In addition, females also demonstrated slight improvements in goal commitment and higher levels of stress at the time, which may also indicate a response shift effect. A more complete picture of the potential moderating effect of gender could be obtained by conducting meta-analytic comparisons of men and women with chronic ill-health conditions involved in social support group interventions compared to men and women with chronic ill-heath conditions not involved in social support group interventions. Similar comparisons would be necessary for a full understanding of the potential moderator effect of culture and minority status.

The possibility also exists that an unknown third variable influenced the reported health outcomes. One possible confounding factor, unemployment, has been discussed in the literature; however, this was beyond the scope of the current meta-analytic review. Further investigation is needed into the effects of unemployment and unemployment duration and how this may have influenced the results of the intervention programmes delivered, particularly for minority members and in economically less developed countries.

Another important consideration is the method of calculation of effect size. In meta-analyses, the studies found often utilise a diverse range of research designs in which some effect sizes might be based on standardised differences in means, whereas others might be based on the correlation between variables. In order to empirically aggregate and synthesise the results from such diverse analyses, the effect sizes must be converted to a common metric. The commonly recommended formulas for equating correlational effect sizes and mean-difference effect sizes may lead to inaccuracies resulting from the application of common equations particularly for small sample sizes. As there is potential for some error in calculation, caution needs to be practised with regard to the interpretation of results. In addition, a broad range of outcome measures were utilised by the studies identified and computation of an overall or "composite" effect size was not possible, as this method requires knowledge of the mean correlations of the variables that would be included in the composite.

Another limitation that requires acknowledgement is that the current research is based on the results of published studies, and hence omits to review studies that were not published. Therefore, if the results of these studies were included it would provide a clearer picture of the ratio of significant and not significant results, placing the current findings in context, and with greater ability to interpret its validity and the conclusions drawn.

The picture for potential confounding variables and moderator effects, such as gender culture, minority status and unemployment, is not yet complete and requires further investigation. In addition, more accurate reporting on the health state of a population is also needed with consistency in the application and utilisation of outcome measures.

On the basis of the identified trends in the studies found, a strong case exists to suggest that social support group interventions are a practical way to assist in the management and prevention of chronic ill-health conditions such as non-communicable 
diseases and injury. However, further research and investigation is required to identify the potential cost-benefits of social support group interventions. Overall, the current analysis demonstrates that social support group interventions can positively influence management of chronic ill-health conditions and contribute to the desired outcome of successful adaptation.

\section{Funding}

This research received no specific grant from any funding agency, commercial or not-for-profit sectors.

\section{Conflicts of Interest}

None.

\section{References}

Armengol, C.G. (1999). A multimodal support group with Hispanic traumatic brain injury survivors. The Journal of Head Trauma Rehabilitation, 14(3), 233-246. doi: http://dx.doi.org/10.1097/00001199-199906000-00004.

Arthur, A.R., \& Edwards, C. (2005). An evaluation of support groups for patients with long-term chronic pain and complex psychosocial difficulties. European Journal of Psychotherapy, Counselling and Health, 7(3), 169-180. doi: http://dx.doi.org/10.1080/13642530500249761.

Chen, Y.-C., Pai, J.-S., \& Li, I.C. (2008). Haemodialysis: The effects of using the empowerment concept during the development of a mutual-support group in Taiwan. Journal of Clinical Nursing, 17(5a), 133-142. doi: http://dx.doi.org/10.1111/j.1365-2702.2007.02186.x.

Cohen, J. (1988). Statistical Power Analysis for the Behavioural Sciences. (2nd ed.). Hillside, NJ: LEA.

Foster, G., Taylor, S.C., Eldridge, S., Ramsay, J., \& Griffiths, C.J. (2009). Self-management programs by lay-leaders for people with chronic conditions (Review). Cochrane Database of Systematic Reviews 2007(4). doi: 10.1002/14651858.CD005108.pub2.

Griffiths, C., Motlib, J., Azad, A., Ramsay, J., Eldridge, S., Feder, G., .. Barlow, J. (2005). Randomised controlled trial of a lay-led self-management programme for Bangladeshi patients with chronic disease. British Journal of General Practice, 55, 831-837.

Handley, M.A., Shumway, M., \& Schillinger, D. (2008). Cost-effectiveness of automated telephone self-management support with nurse care management among patients with diabetes. Annals of Family Medicine, 6(6), 512-518.

Haugli, L., Steen, E., Laerum, E., Nygard, R., \& Finset, A. (2001). Learning to have less pain is it possible? A one-year follow-up study of the effects of a personal construct group learning programme on patients with chronic musculoskeletal pain. Patient Education $\mathcal{E}$ Counseling, 45(2), $111-118$.

Hill, W., Weinert, C., \& Cudney, S. (2006). Influence of a computer intervention on the psychological status of chronically ill rural women: Preliminary results. Nursing Research, 55(1), 34-42. doi: http://dx.doi.org/10.1097/00006199-200601000-00005.

Hill, W., Weinert, C., \& Schillo, L. (2004). Effect of computer-based intervention on social support for chronically ill rural women. Rehabilitation Nursing Journal, 29(5), 169.

Jones, R.J., \& Azrin, N.H. (1973). An experimental applicaion of a social reinforcement approach to the problem of job-finding. Journal of Applied Behavior Analysis, 6, 345-353.

Katz, N., Amick, B., keller, R., Fossell, A., Ossmaan, J., Soucie, V. et al. (2005). Determinanats of work absence following surgeery for Carpel Tunnel Syndrome. American Journal of Industrial Medicine, 47, 120-130. 
Kennedy, A., Reeves, D., Bower, P., Lee, V., Middleton, E., Richardson, G., ... Rogers, A. (2007). The effectiveness and cost effectiveness of a national lay-led self care support programme for patients with long-term conditions: A pragmatic randomised controlled trial. Journal of Epidemiology Eु Community Health, 61(3), 254-261.

Krause, M. (2003). The transformation of social representations of chronic disease in a self-help group. Journal of Health Psychology, 8(5), 599-615.

Lieberman, M., Golant, M., Giese-Davis, J., Winzlenberg, A., Benjamin, H., Humphreys, K., ... Spiegel, D. (2003). Electronic support groups for breast carcinoma: A clinical trial of effectiveness. Cancer, 97(4), 920-925. doi: 10.1002/cncr.11145.

Linton, S.J., Hellsing, A.-L., \& Larsson, I. (1997). Bridging the gap: Support groups do not enhance long-term outcome in chronic back pain. The Clinical Journal of Pain, 13(3), 221-228. doi: http://dx.doi.org/10.1097/00002508-199709000-00007.

Lipsey, M.W., \& Wilson, D.B. (2001). Practical Meta-Analysis. Beverley Hills: Sage Publications.

Lorig, K.R., \& Holman, H.R. (2003). Self-management education: History, definition, outcomes, and mechanisms. Annals of Behavioral Medicine, 26(1), 1-7.

Lorig, K., Ritter, P., \& Jacquez, A. (2005). Outcomes of border health Spanish/English chronic disease self-management programs. Diabetes Educator, 31(3), 401-409.

Muenchberger, H., Kendall, E., Kennedy, A., \& Charker, J. (2011). Living with brain injury in the community: Outcomes from a community-based self-management support (CB-SMS) programme in Australia. Brain Injury, 25(1), 23-34. doi: 10.3109/02699052.2010.531689.

Murphy, G.C., \& O'Hare, M.A. (2016). The role of workplace social support in disability management. In T. Geisen \& H. Harder (eds.), Disability Management and Workplace Intergration: International Research Findings (pp. 43-58). London: Routledge.

Osborne, R., Hawkins, M., \& Sprangers, M. (2006). Change of perspective: A measurable and desired outcome of chronic disease self-management intervention programs that violates the premise of preintervention/postintervention assessment. Arthritis $\mathcal{G}$ Rheumatism, 55, 458-465.

Ownsworth, T., McFarland, K., \& Young, R. (2000). Self-awareness and psychosocial functioning following acquired brain injury: An evaluation of a group support programme. Neuropsychological Rehabilitation, 10(5), 465-484. doi: http://dx.doi.org/10.1080/09602010050143559.

Rosenthal, R. (1994). Parametric Measures of Effect Size. In H. Cooper \& L. V. Hedges (eds.) (pp. 231-244). New York: Sage.

Social Research Centre (2016). Return to Work Survey, 2016. Headline Measures Report. Australia. Canberra: Safe Work Australia.

Struchen, M.A., Davis, L.C., Bogaards, J.A., Hudler-Hull, T., Clark, A.N., Mazzei, D.M., ... Caroselli, J.S. (2011). Making connections after brain injury: Development and evaluation of a social peer-mentoring program for persons with traumatic brain injury. Journal of Head Trauma Rehabilitation, 26(1), 4-19. doi: http://dx.doi.org/10.1097/HTR.0b013e3182048e98.

Subramaniam, V., Stewart, M.W., \& Smith, J.F. (1999). The development and impact of a chronic pain support group: A qualitative and quantitative study. Journal of Pain $\mathcal{E}$ Symptom Management, 17(5), 376-383.

Thomas, M. (2004). The potential unlimited programme: An outdoor experiential education and group work approach that facilitates adjustment to brain injury. Brain Injury, 18(12), 1271-1286.

Weinert, C., Cudney, S., Comstock, B., \& Bansal, A. (2011). Computer intervention impact on psychosocial adaptation of rural women with chronic conditions. Nursing Research, 60(2), 8291. doi: 10.1097/NNR.0b013e3181ffbcf2.

Weinert, C., Hill, W., \& Cudney, S. (2008). Rural women, technology, and self-management of chronic illness. Canadian Journal of Nursing Research, 40(3), 114-134.

Wolf, F.M. (1986). Meta-analysis: Quantitative Methods for Research Synthesis. Beverley Hill: Sage Publications. 